\title{
PEMANFAATAN SOFTWARE BERBASIS MATRIK DALAM PERHITUNGAN KONSTRUKSI STATIS TAK TENTU PADA MEKANIKA TEKNIK LANJUT
}

\author{
Muh. Khotibul Umam Hs \\ Jurusan Pendidikan Teknik Mesin FT UNY \\ muh_khotibul_umam@yahoo.com
}

\begin{abstract}
Along with the rapid development of personal computers, the use of computer software for various purposes is also increased. The calculation in engineering mechanics course, especially in the process of calculating statically indeterminate structures, the use of matrix is essentials. Matrix calculation were once considered less favorable, particularly in higher order matrices. It became much easier and much faster after the use of computer software capable of processing the matrix calculation. The advantages of using computer software for matrix calculation can also be used for engineering calculations in general.
\end{abstract}

Keywords: computer software, matrix, statically indeterminate construction, engineering mechanics

\begin{abstract}
ABSTRAK
Sejalan dengan pesatnya perkembangan komputer pribadi, penggunaan perangkat lunak komputer untuk berbagai keperluan juga semakin meningkat. Pada perhitungan mata kuliah mekanika teknik, terutama pada proses perhitungan konstruksi statis tak tentu, penggunaan matrik yang sebelumnya dianggap sebagai perhitungan yang kurang menguntungkan, terutama pada matrik yang berordo tinggi, menjadi jauh lebih mudah dan cepat dengan bantuan perangkat lunak komputer yang berkemampuan mengolah matrik. Manfaat dari pemanfaatan perangkat lunak ini dapat digunakan sebagai alat bantu perhitungan matrik keperluan teknik secara umum. Penggunaan perangkat lunak komputer berbasis matrik pada proses perhitungan konstruksi statis tak tentu mempunyai beberapa keuntungan dibanding dengan metode lainnya yaitu: (a) membutuhkan pemahaman yang lebih mudah, (b) tingkat akurasi bisa didapat sesuai dengan keinginan, (c) kecepatan penyelesaian yang tinggi.
\end{abstract}

Kata Kunci: Perangkat lunak komputer, matrik, konstruksi statis tak tentu, mekanika teknik

\section{PENDAHULUAN}

Metode matrik adalah salah satu metode perhitungan yang banyak dipakai pada berbagai hal, diantaranya digunakan untuk representasi, perhitungan, studi linear pemetaan, dan finite group. Selain itu matrik juga berkembang menjadi dasar 2D, 3D dan 4G geometri (math.stackexchange.com). Cara ini mempunyai logika pemahaman yang sederhana, tetapi pada tingkat matrik yang tinggi (lebih dari $4 \times 4$ ) metode ini banyak ditinggalkan karena membutuhkan perhitungan yang berulang-ulang dan perlu kecermatan yang tinggi untuk mendapatkan hasil yang baik (www.decodedscience.org).

Sejalan dengan perkembangan personal computer (PC) atau komputer pribadi yang pesat, dan diikuti pula dengan meningkatnya kemampuan perangkat lunaknya (Pusat Data Informasi dan Pertahanan RI, 2014), maka penggunaan matrik sebagai suatu metode perhitungan pada berbagai bidang teknik, terutama bidang konstruksi, menjadi salah satu pilihan yang cukup menarik (news.MIT.edu). Perkalian matrik dan operasi lainnya seperti determinan matrik, invers matrik, transpose matrik dan sebagainya, yang sebelumnya membutuhkan waktu yang panjang dan kecermatan yang tinggi untuk menyelesaikan, dengan bantuan perangkat lunak komputer hanya membutuhkan waktu yang sangat pendek, tetapi dengan hasil yang memuaskan.

Demikian pula pilihan akan jenis perangkat lunak menjadi semakin beragam. Dari mulai perangkat lunak yang murni 
berbasis matrik seperti ANSYS dan Nastran, maupun yang sifatnya umum seperti Matlab, Mathcad dan Maple, menjadi alternatif yang dapat dimanfaatkan karena berkemampuan mengolah matrik sampai lebih dari 100x100 dengan kecepatan yang tinggi.

Perhitungan menggunakan metode matriks tersebut banyak digunakan pada mata kuliah Mekanika Teknik Lanjut. Silabus perkuliahan Mekanika Teknik Lanjut (Umam: 2010) menjelaskan bahwa kompetensi yang harus dikuasai oleh mahasiswa adalah: (1) dapat menghitung defleksi yang terjadi pada konstruksi statis tertentu, (2) menghitung besar kakas reaksi pada konstruksi statis tak tentu melalui prinsip defleksi dengan menggunakan metode langsung, fungsi bertingkat, maupun superposisi, (3) mampu membuat normal force diagram (NFD), shearing force diagram (SFD) dan bending moment diagram (BMD) dari berbagai macam konstruksi statis tak tentu, (4) memahami prinsip metode elemen hingga dan menerapkannya pada proses perhitungan defleksi pada balok menerus dan rangka batang yang mempunyai bentuk konstruksi statis tak tentu, (5) memanfaatkan beberapa perangkat lunak komputer seperti Microsoft Excel, Matlab maupun Ansys untuk membantu proses perhitungan.

Pengembangan proses perhitungan dengan menggunakan matrik bertujuan agar lebih mudah diaplikasikan pada mata kuliah Mekanika Teknik Lanjut khususnya pada perhitungan konstruksi statis tak tentu. Mahasiswa diharapkan dapat menggunakan beberapa perangkat lunak komputer sebagai alat bantu dalam menganalisa konstruksi statis tak tentu tersebut.

\section{METODE}

Penelitian ini merupakan penelitian pengembangan dengan objek penelitian yaitu penggunaan aplikasi komputer sebagai alat bantu dalam perhitungan matriks. Software yang ada diuji coba untuk menghitung matriks berordo tinggi dengan dikomparasikan dengan hasil perhitungan secara manual dan kemudian dilihat tingkat kesalahan yang terjadi diantaranya keduanya.

\section{HASIL DAN PEMBAHASAN}

Penggunaan perangkat lunak komputer pada penyelesaian persoalan teknik adalah proses pengubahan persamaan teknik yang ada, yang pada umumnya banyak mempunyai persamaan deffrensial, menjadi persamaan yang lebih sederhana tetapi harus diselesaikan berulang-ulang. Persamaan deffrensial tersebut kemudian diubah menjadi persamaan lain yang mudah diselesaikan tetapi perhitungannya harus dilakukan secara berulang-ulang. Hal tersebut untuk mendapatkan persamaan yang dapat dihitung dengan perangkat lunak komputer.
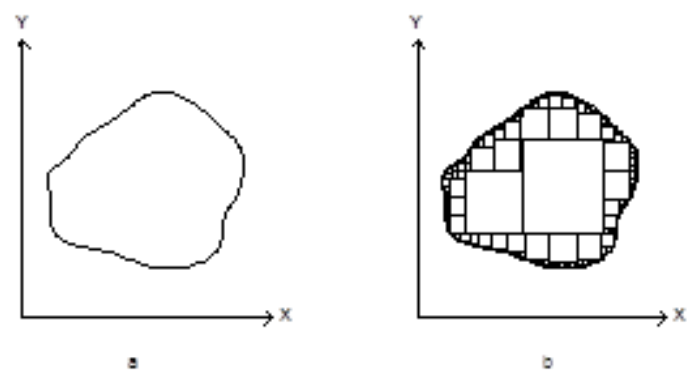

Gambar 1. Perhitungan luas suatu daerah

Contoh sederhana pada perhitungan luas suatu daerah sebagaimana ditunjukkan pada Gambar 1a. Perhitungan dapat diselesaikan dengan melakukan proses integrasi terhadap persamaan garis yang membatasi daerah tersebut. Semakin rumit bentuk garis batasnya, maka semakin komplek pula persamaannya, dan penyelesaiannya pun akan semakin sulit. Untuk menghindari kesulitan ini, luas daerah kemudian dibagi menjadi beberapa bujur sangkar ukuran kecil sebagaimana ditunjukkan Gambar 1b, dan perhitungan luas didasarkan pada luas dan jumlah semua bujur sangkar yang ada. Hal yang diperhatikan bahwa ukuran tiap bujur sangkar adalah tidak sama. Semakin kecil ukuran bujur sangkarnya , terutama pada daerah perbatasan, maka akan semakin baik 
hasilnya, tetapi akan semakin lama pula penyelesaiannya. Konsep dasar itulah yang dipakai pada metode elemen hingga, yaitu membagi suatu benda kerja yang besar, menjadi bentuk-bentuk kecil yang sesuai dengan sifat pada bagian-bagian kecil tersebut.

Pembagian daerah-daerah kecil itu, yang umum disebut elemen, biasanya didasarkan pada perubahan bentuk, penampang, sifat benda, maupun perubahan gaya yang bekerja pada suatu titik. Persoalan-persoalan statika, misalnya perhitungan normal force diagram (NFD), shearing force diagram (SFD) yang biasa dipelajari pada mata kuliah Mekanika Teknik Lanjut juga dapat diselesaikan dengan cara seperti yang dijelaskan tersebut. Sebagai gambaran, perhatikan gambar konstruksi poros bertingkat pada Gambar 2.

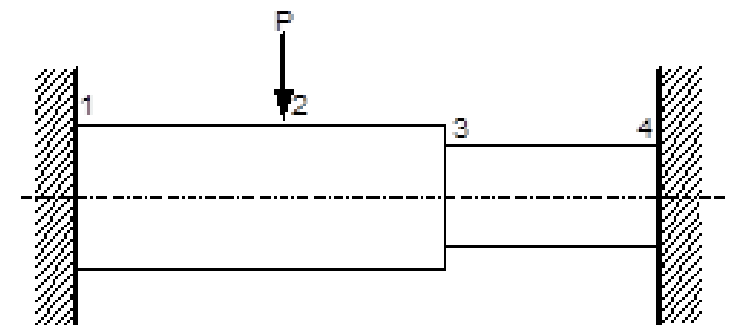

Gambar 2. Poros bertingkat dengan konstruksi statis tak tentu

Pembagian yang paling sederhana dan menguntungkan pada konstruksi di atas adalah dengan membaginya menjadi tiga elemen, yaitu elemen 1 yang dimulai dari titik 1 sampai titik 2, elemen 2 yang dimulai dari titik 2 sampai titik 3, dan elemen ketiga yang dimulai dari titik 3 sampai titik 4. Pembagian jumlah elemen ini tidak bersifat mutlak, tetapi tergantung pada tingkat akurasi yang dibutuhkan. Tingkat akurasi yang diinginkan semakin tinggi, maka ukuran tiap elemen harus dibuat semakin kecil. Namun demikian, pembagian jumlah elemen tersebut juga harus memperhatikan adanya perubahan yang terjadi pada konstruksi. Tiap perubahan seyogyanya menjadi titik ujung dari elemen. Sebagai contoh, apabila antara titik 1 dan titik 3 dikehendaki dibagi menjadi tiga elemen, maka pembagian yang baik adalah titik 1 sampai 2 menjadi elemen pertama dan dua elemen yang lain didapatkan dengan cara membagi antara titik 2 dan 3 menjadi elemen 2 dan elemen tiga. Pola yang lain adalah antara titik 1 dan 2 dibagi menjadi dua elemen, dan elemen ketiga adalah antara titik 2 dan 3. Dengan kata lain, meletakkan titik 2 berada di tengah-tengah elemen sebaiknya dihindari.

Proses perhitungan pada mekanika benda tegar banyak didasarkan pada Hukum Hook, sebagaimana ditunjukkan pada persamaan 1 di bawah ini.

$$
\sigma=\varepsilon \cdot E=\frac{F}{A}
$$

dimana:

$\sigma=$ tegangan yang terjadi pada benda

$\varepsilon=$ regangan (penambahan panjang $(\Delta L)$

berbanding panjang semula $(L))$

$E=$ modulus elastisitas bahan

$F=$ gaya yang bekerja pada benda

$A=$ Luas penampang benda .
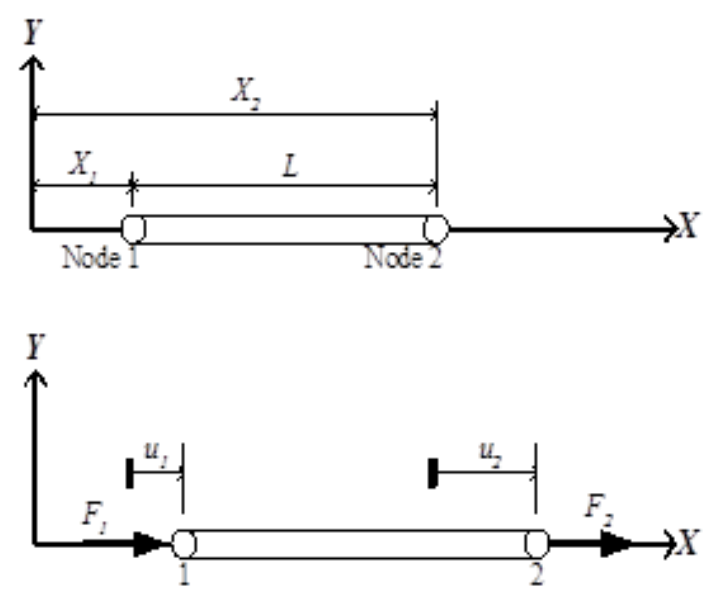

Gambar 3. Pergeseran benda akibat gaya $\mathrm{F}$

Gambar di atas dapat dijelaskan bahwa penambahan panjang $(\Delta L)$ benda akibat adanya $F$ adalah:

$$
\Delta L=u_{2}-u_{1}
$$

dimana:

$u_{1}, u_{2}=$ pergeseran pada titik (node) 1 dan titik 2

Dengan demikian, persamaan (1) berubah menjadi: 


$$
\Delta L=\frac{F L}{A E}
$$

Jika kekakuan benda dinyatakan sebagai:

$$
k=\frac{F}{\Delta L}
$$

maka dari persamaan (3) dan (4) dapat dihasilkan kekakuan benda $(k)$ :

$$
k=\frac{A E}{L}
$$

Berdasarkan Gambar 3 di atas, yang mana terdapat $F_{1}$ dan $F_{2}$ pada node 1 dan node 2, maka besarnya gaya yang bekerja pada masing-masing titik adalah:

$$
\begin{aligned}
& F_{1}=k\left(u_{1}-u_{2}\right) \\
& F_{2}=k\left(u_{2}-u_{1}\right)
\end{aligned}
$$

Yang secara matrik dapat dituliskan sebagai:

$$
\left\{\begin{array}{l}
F_{1} \\
F_{2}
\end{array}\right\}=k\left[\begin{array}{cc}
1 & -1 \\
-1 & 1
\end{array}\right]\left\{\begin{array}{l}
u_{1} \\
u_{2}
\end{array}\right\}
$$

atau $\quad\{\boldsymbol{F}\}=[\boldsymbol{k}] \cdot\{\boldsymbol{u}\}$

dimana:

$\{\boldsymbol{F}\}=\left\{\begin{array}{l}F_{1} \\ F_{2}\end{array}\right\}=$ matrik vektor beban pada titiktitik elemen

$[k]=k\left[\begin{array}{cc}1 & -1 \\ -1 & 1\end{array}\right]=\frac{A E}{L}\left[\begin{array}{cc}1 & -1 \\ -1 & 1\end{array}\right]=$ matrik

kekakuan elemen

$\{\boldsymbol{u}\}=\left\{\begin{array}{l}u_{1} \\ u_{2}\end{array}\right\}=$ matrik pergeseran titik-titik pada elemen

Matrik kekakuan benda pada persamaan (6) adalah matrik yang didasarkan pada pergeseran ke arah $X$ saja. Pada kenyataannya, suatu benda jarang sekali bergerak hanya pada satu arah. Setidaknya, suatu benda akan bergeser ke dua arah. bahkan pada umumnya bergerak ke tiga arah sumbu yaitu $X, Y$ dan $Z$. Matrik kekakuan benda yang bergeser ke arah
$\mathrm{X}$ dan $\mathrm{Y}$ dapat diperoleh sebagaimana ditunjukkan pada Gambar 4.

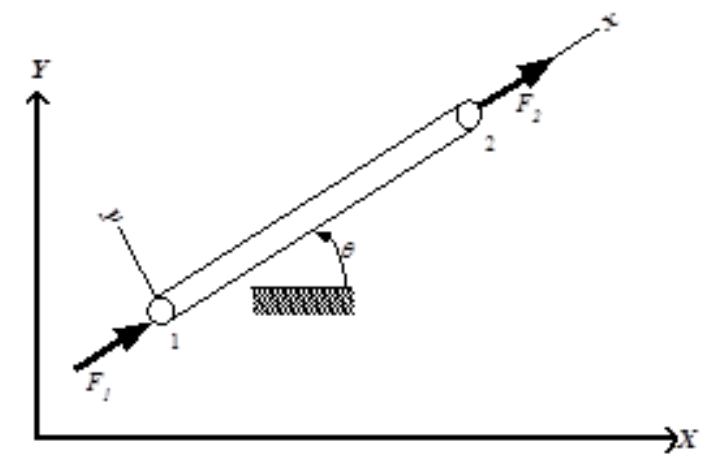

Gambar 4. Pergeseran benda pada $X$ dan $Y$

Matrik kekakuan pada persamaan (6) dapat diubah menjadi matrik kekakuan benda yang bergeser ke dua arah, yaitu dengan menambahkan angka nol pada anggota matrik yang bersesuaian dengan arah $Y$, sehingga persamaan (6) berubah menjadi:

$\left\{\begin{array}{l}F_{1 x} \\ F_{1 y} \\ F_{2 x} \\ F_{2 y}\end{array}\right\}=\frac{A E}{L}\left[\begin{array}{cccc}1 & 0 & -1 & 0 \\ 0 & 0 & 0 & 0 \\ -1 & 0 & 1 & 0 \\ 0 & 0 & 0 & 0\end{array}\right]\left\{\begin{array}{l}u_{1 x} \\ u_{1 y} \\ u_{2 x} \\ u_{2 y}\end{array}\right\}$

Persamaan (7) di atas didasarkan pada sistem koordinat lokal, yaitu suatu sistem koordinat yang dibuat dengan meletakkan sumbu $x$ berimpit dengan arah kemiringan elemen benda. Matrik kekakuan yang dibuat dengan sistem koordinat lokal tersebut hanya berlaku pada elemen itu saja, dan tidak berlaku bagi elemen lain. Untuk mengubahnya menjadi matrik kekakuan yang berlaku keseluruhan (global) digunakan formula berikut:

$\left.[k]_{\mathrm{XY}}=[\boldsymbol{T r}] .[k]_{\mathrm{xy} \cdot[\boldsymbol{T r}}\right]^{\mathrm{T}}$

dimana:

$[\boldsymbol{T r}]=$ matrik transformasi $=$

$\left[\begin{array}{cccc}\cos \theta & -\sin \theta & 0 & 0 \\ \sin \theta & \cos \theta & 0 & 0 \\ 0 & 0 & \cos \theta & -\sin \theta \\ 0 & 0 & \sin \theta & \cos \theta\end{array}\right]$ 
Penerapan perhitungan tersebut di atas dapat digunakan pada pembelajaran Mekanika Teknik Lanjut khususnya untuk menghitung defleksi yang terjadi pada konstruksi statis tertentu atau menghitung besar kakas reaksi pada konstruksi statis tak tentu. Perhitungan dapat dilakukan secara manual untuk menguji tingkat pemahaman materi dan menggunakan aplikasi komputer untuk membuktikan ketepatan hasil perhitungan manual tersebut..

Prosedur penggunaan perangkat lunak komputer ini pada perhitungan konstruksi statis tak tentu dijelaskan melalui contoh berikut ini. Contoh kasus ini diselesaikan dengan menggunakan Matlab. Penyelesaian ini dapat juga dikombinasikan dengan Microsoft Excel untuk memberikan gambaran langkah demi langkah penyelesaian soal.

Soal: Tentukan semua gaya yang bekerja pada struktur seperti ditunjukkan pada Gambar 5 di bawah, dan tentukan pergeseran vertikal pada titik A. Luas penampang melintang tiap batang adalah $50 \mathrm{~mm}^{2}$ dengan modulus elastisitas $(\mathrm{E})=1,5.10^{5} \mathrm{MPa}$.
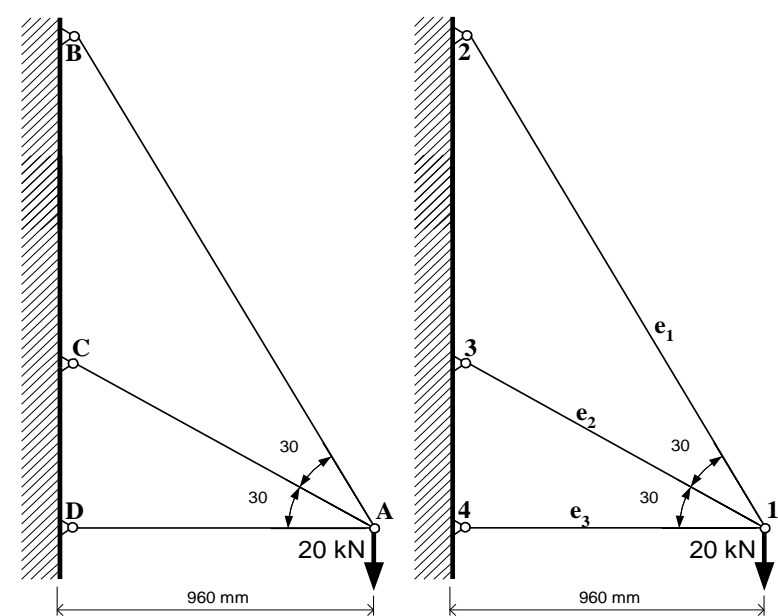

Gambar 5. (a) Konstruksi soal, (b) Pola peletakan node pada konstruksi

Langkah penyelesaian adalah sebagai berikut: diasumsikan bahwa bahan dianggap 61sotropic, dan konstruksi dibagi dalam tiga elemen, yaitu $\mathrm{AB}$ sebagai elemen 1, AC sebagai elemen 2, dan AD sebagai elemen 3. Dengan demikian titik-titik pada konstruksi di atas berubah menjadi pola pada Gambar 5 (b).
Untuk menyelesaikan soal di atas, dilakukan tinjauan pada tiap elemen: (a) Elemen 1 dengan sudut $\theta=120^{\circ}$ (diukur dari sumbu $X$ positif dengan arah berlawanan jarum jam). Titik 1 pada koordinat global menjadi node 1 pada elemen 1, dan titik 2 pada koordinat global menjadi node 2. (b) Elemen 2 bersudut $150^{\circ}$, dengan node 1 pada koordinat global menjadi node 1 pada elemen 2, dan titik 3 pada koordinat global menjadi node 2. (c) Elemen 3 bersudut $180^{\circ}$, dengan node 1 pada koordinat global menjadi node 1 pada elemen 3, dan titik 4 pada koordinat global menjadi node 2 .

Matrik kekakuan elemen diperoleh dengan menggunakan persamaan (8) dan (9), dan hasilnya adalah:

$$
\begin{aligned}
& {[k]_{X Y 1}=10^{5}\left[\begin{array}{cccc}
9,77 & -16,91 & -9,77 & 16,91 \\
-16,91 & 29,3 & 16,91 & -29,3 \\
-9,77 & 16,91 & 9,77 & -16,91 \\
16,91 & -29,3 & -16,91 & 29,3
\end{array}\right] \ldots(10)} \\
& {[k]_{X Y 2}=10^{5}\left[\begin{array}{cccc}
50,74 & -29,3 & -50,74 & 29,3 \\
-29,3 & 16,91 & 29,3 & -16,91 \\
-50,74 & 29,3 & 50,74 & -29,3 \\
29,3 & -16,91 & -29,3 & 16,91
\end{array}\right] \ldots(11)} \\
& {[k]_{X Y 3}=10^{5}\left[\begin{array}{cccc}
78,12 & 0 & -78,12 & 0 \\
0 & 0 & 0 & 0 \\
-78,12 & 0 & 78,12 & 0 \\
0 & 0 & 0 & 0
\end{array}\right] \ldots .(12)}
\end{aligned}
$$

Ketiga matrik kekakuan di atas menggunakan sistem koordinat global, tetapi hanya berlaku bagi masing-masing elemen. Untuk mendapatkan matrik kekakuan yang berlaku untuk seluruh konstruksi, ketiga matrik kekakuan elemen itu harus digabungkan dengan memperhatikan posisi tiap-tiap komponen matrik.

Secara keseluruhan, konstruksi mempunyai 3 elemen dan dengan 4 titik. Karena masing-masing titik dapat bergeser pada arah $X$ dan $Y$, maka matrik kekakuan yang berlaku untuk seluruh konstruksi mempunyai ukuran $(4 \times 2) x(4 \times 2)$ atau matrik 
8x8. Dengan demikian persamaan (7) yang berlaku bagi seluruh konstruksi adalah:

$\left.\left\{\begin{array}{l}F_{1 X} \\ F_{1 Y} \\ F_{2 X} \\ F_{2 Y} \\ F_{3 X} \\ F_{3 Y} \\ F_{4 X} \\ F_{4 Y}\end{array}\right\}=\left[\begin{array}{llllllll}K_{11} & K_{12} & K_{13} & K_{14} & K_{15} & K_{16} & K_{17} & K_{18} \\ K_{21} & K_{22} & K_{23} & K_{24} & K_{25} & K_{26} & K_{27} & K_{28} \\ K_{31} & K_{32} & K_{33} & K_{34} & K_{35} & K_{36} & K_{37} & K_{38} \\ K_{41} & K_{42} & K_{43} & K_{44} & K_{45} & K_{46} & K_{47} & K_{48} \\ K_{51} & K_{52} & K_{53} & K_{54} & K_{55} & K_{56} & K_{57} & K_{58} \\ K_{61} & K_{62} & K_{63} & K_{64} & K_{65} & K_{66} & K_{67} & K_{68} \\ K_{71} & K_{72} & K_{73} & K_{74} & K_{75} & K_{76} & K_{77} & K_{78} \\ K_{81} & K_{82} & K_{83} & K_{84} & K_{85} & K_{86} & K_{87} & K_{88}\end{array}\right] \begin{array}{l}u_{1 X} \\ u_{1 Y} \\ u_{2 X} \\ u_{2 Y} \\ u_{3 X} \\ u_{3 Y} \\ u_{4 X} \\ u_{4 Y}\end{array}\right\}$

Untuk mendapatkan semua komponen matrik di atas, dapat dilakukan dengan menjumlahkan semua matrik kekakuan elemen yang ada. Harus diperhatikan bahwa matrik kekakuan elemen hanya untuk dua node, yaitu titik 1 dan titik 2 pada masing-masing elemen. Sedangkan matrik kekakuan pada persamaan 11, diperuntukkan bagi 4 node pada semua elemen. Oleh karena itu penjumlahan semua matrik kekakuan yang ada harus memperhatikan kesesuaian antara node pada elemen dan node pada konstruksi total.

Sebagai contoh, pada matrik kekakuan untuk elemen 1, komponen baris 1 dan 2 yang terletak pada kolom 1 dan 2 pada matrik tersebut bersesuaian dengan node 1 pada konstruksi. Sedangkan komponen baris 3 dan 4 yang terletak pada kolom 3 dan 4 pada matrik tersebut bersesuaian dengan node 2 pada konstruksi. Demikian juga pada matrik kekakuan untuk elemen 2 baris 1 dan 2 yang terletak pada kolom 1 dan 2 matrik ini sesuai dengan node 1 pada konstruksi, sedang baris 3 dan 4 pada kolom 3 dan 4 sama dengan node 3 pada konstruksi.

Cara termudah untuk mendapatkan matrik kekakuan konstruksi adalah dengan mengubah pola matrik kekakuan elemen yang semula matrik $4 \times 4$, menjadi matrik $8 \times 8$ sesuai dengan matrik kekakuan konstruksi. Perubahan itu dengan menambahkan bilangan nol pada bagian yang tidak ada. Sebagai contoh matrik kekakuan elemen 2 yang mempunyai komponen titik 1 dan 3. Semua komponen untuk node 2 dan 4 yang tidak dipunyai oleh matrik ini diisi dengan nol, sehingga matrik kekakuan elemen 2 berubah menjadi:

$$
[k]_{X Y 2}=10^{5}\left[\begin{array}{cccccccc}
50,74 & -29,3 & 0 & 0 & -50,74 & 29,3 & 0 & 0 \\
-29,3 & 16,91 & 0 & 0 & 29,3 & -16,91 & 0 & 0 \\
0 & 0 & 0 & 0 & 0 & 0 & 0 & 0 \\
0 & 0 & 0 & 0 & 0 & 0 & 0 & 0 \\
-50,74 & 29,3 & 0 & 0 & 50,74 & -29,3 & 0 & 0 \\
29,3 & -16,91 & 0 & 0 & -29,3 & 16,91 & 0 & 0 \\
0 & 0 & 0 & 0 & 0 & 0 & 0 & 0 \\
0 & 0 & 0 & 0 & 0 & 0 & 0 & 0
\end{array}\right]
$$

Dengan pola yang sama didapatkan matrik kekakuan elemen 1 dan 3, yang kemudian dijumlahkan untuk mendapatkan matrik kekakuan konstruksi:

$$
[K]_{\text {TOTAL }}=10^{6}\left[\begin{array}{cccccccc}
13,86 & -4,62 & -0,98 & 1,69 & -5,07 & 2,93 & -7,81 & 0 \\
-4,62 & 4,62 & 1,69 & -2,93 & 2,93 & -1,69 & 0 & 0 \\
-0,98 & 1,69 & 0,98 & -1,69 & 0 & 0 & 0 & 0 \\
1,69 & -2,93 & -1,69 & 2,93 & 0 & 0 & 0 & 0 \\
-5,07 & 2,93 & 0 & 0 & 5,07 & -2,93 & 0 & 0 \\
2,93 & -1,69 & 0 & 0 & -2,93 & 1,69 & 0 & 0 \\
-7,81 & 0 & 0 & 0 & 0 & 0 & 7,81 & 0 \\
0 & 0 & 0 & 0 & 0 & 0 & 0 & 0
\end{array}\right]
$$

Gambar 5 (b) diketahui bahwa gaya yang bekerja titik 2, 3 dan 4 belum diketahui besarnya, baik ke arah sumbu- $X$ maupun sumbu sumbu- $Y$. Sedangkan pada titik 1 besar gaya ke arah sumbu- $X$ sama dengan nol, dan ke arah sumbu- $Y$ sebesar $20 \mathrm{kN}$. Dari gambar tersebut juga diketahui bahwa pergeseran titik 2, 3 dan 4, baik ke arah sumbu- $X$ maupun sumbu- $Y$ sama dengan nol. Sedangkan pergeseran titik 1 belum diketahui besarnya. Dengan demikian persamaan (13) menjadi:

$\left\{\begin{array}{c}0 \\ -20000 \\ F_{2 X} \\ F_{2 Y} \\ F_{3 X} \\ F_{3 Y} \\ F_{4 X} \\ F_{4 Y}\end{array}\right\}=10^{6}\left[\begin{array}{cccccccc}13,86 & -4,62 & -0,98 & 1,69 & -5,07 & 2,93 & -7,81 & 0 \\ -4,62 & 4,62 & 1,69 & -2,93 & 2,93 & -1,69 & 0 & 0 \\ -0,98 & 1,69 & 0,98 & -1,69 & 0 & 0 & 0 & 0 \\ 1,69 & -2,93 & -1,69 & 2,93 & 0 & 0 & 0 & 0 \\ -5,07 & 2,93 & 0 & 0 & 5,07 & -2,93 & 0 & 0 \\ 2,93 & -1,69 & 0 & 0 & -2,93 & 1,69 & 0 & 0 \\ -7,81 & 0 & 0 & 0 & 0 & 0 & 7,81 & 0 \\ 0 & 0 & 0 & 0 & 0 & 0 & 0 & 0\end{array}\right]\left\{\begin{array}{c}u_{1 X} \\ u_{1 Y} \\ 0 \\ 0 \\ 0 \\ 0 \\ 0 \\ 0\end{array}\right\}$

Dengan menggunakan Matlab, proses perhitungan untuk mendapatkan matrik 
kekakuan itu secara lengkap dapat dilihat pada Program 1.

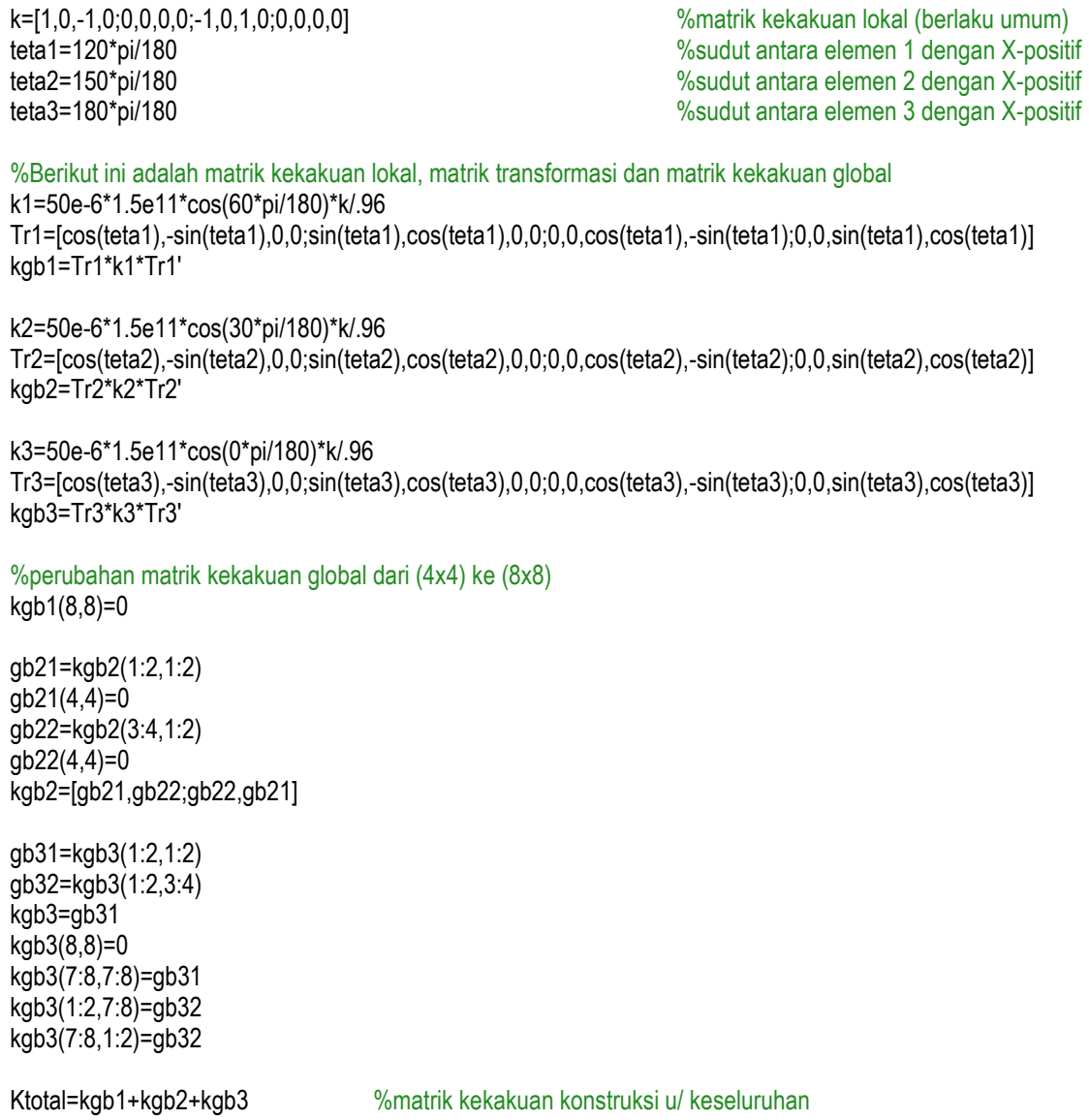

\%matrik kekakuan lokal (berlaku umum)

\%sudut antara elemen 1 dengan X-positif

$\%$ sudut antara elemen 2 dengan X-positif

\%sudut antara elemen 3 dengan X-positif

Dari baris pertama dan kedua pada persamaan matrik di atas, didapatkan:

Program 1. Penentuan matrik kekakuan dengan MATLAB

Pergeseran yang dihasilkan node 1 ke arah $X$ $\left(u_{1 X}\right)$ dan ke arah $Y\left(u_{1 Y}\right)$ sebesar:

$u_{1 X}=-0,0021645 \mathrm{~m}=2,1645 \mathrm{~mm}$

$u_{1 Y}=-0.0064935 \mathrm{~m}=6,4935 \mathrm{~mm}$

Sedangkan besar gaya yang bekerja pada masing-masing tumpuan adalah:

$\mathrm{F}_{2 X}=0.0089 \mathrm{~N}$

$\mathrm{F}_{2 Y}=-0.0138 \mathrm{~N}$

Atau gaya yang bekerja pada node 2 sebesar $16,421 \mathrm{kN}$. Sedangkan pada node 3 , besar gaya yang bekerja adalah:

$\mathrm{F}_{3 X}=0.0081 \mathrm{~N}$

$\mathrm{F}_{3 Y}=-0.0046 \mathrm{~N}$ 
muncul tersebut, yang tak lebih dari 5\%, salah satunya adalah akibat pembulatan perhitungan. Dengan demikian dapat disimpulkan bahwa hasil perhitungan tersebut dapat dipertanggung-jawabkan.

\section{SIMPULAN}

Penggunaan perangkat lunak komputer berbasis matrik pada proses perhitungan konstruksi statis tak tentu mempunyai beberapa keuntungan dibanding dengan metode lainnya. Keuntungan itu antara lain: (a) membutuhkan pemahaman yang lebih mudah, (b) tingkat akurasi bisa didapat sesuai dengan keinginan, (c) kecepatan penyelesaian yang tinggi

\section{DAFTAR RUJUKAN}

Cook, Robert D. 1990. Konsep dan Aplikasi Metode Elemen Hingga. Bandung: Eresco

Grandin, Hartley Jr. 1986. Fundamentals of the Finite Element Method. New York: Macmillan Publishing Company

Hall, A.S. 1973. An Introduction to The Mechanics of Solids. Sydney: John Willey \& Sons Australasia Pty Ltd
Larry, H. 2013. Explained: Matrice. http://news.mit.edu/2013/explained.matr ice.2105695. Diakses pada 20 Juli 2016

Mike, D. 2013. Practical Use of Matrice Mathematic. Diakses melalui www.decodedscience.org/practical-useof-mathematic pada 18 Juli 2016

Moaveni, Saeed. 1999. Finite Element Analysis Theory and Application with ANSYS. New Jersey: Prentice Hall Inc

Palm, William J. III. 1999. MATLAB ${ }^{\circledR}$ For Engineering Application. New York:The McGraw-Hill Companies

Pusat Data dan Informasi Kementerian Pertahanan RI. 2014. Pertumbuhan Komputer Indonesia Paling Pesat di Dunia. Diakses melalui www.pusditkemhan.go.id pada 2 Februari 2016

What is the usefulness of matrice? Diakses melalui www.math.stackexchange.com/160328 pada 17 Agustus 2016

Yang, T.Y. 1986. Finite Element Structural Analysis. New Jersey: Prentice Hall Inc 